\title{
Relative Movements in Wages and Profits
}

\author{
by ALBERT E. BURGER
}

Controlling prices and wages involves the Government heavily in determining the relations between wages and profits in general and in particular industries and sectors and in many other aspects of the distribution of income. This Goverment in" volvement raises the question of the faimess of the outcome. The meaning of the question itself is difficult because, of course, people will differ about what a fair outcome would be. ${ }^{1}$

The American economy is presently experiencing a strong upswing from the $1969-70$ recession. Con current with the economic recovery, gains in wages and salaries and in corporate profits have accelerated. From the third quarter of 1970 to the third quarter of 1972, corporate after-tax profits in the nonfinancial sector have risen at a 14.2 percent annual rate and compensation of employees at a 7.3 percent rate.

Since prices and wage rates have been subject to control under the New Economic Program begun in August 1971, some observers have viewed the more rapid rise in corporate profits as reflecting a bias of the control program. Concem has been expressed that distribution of the share of income originating in the corporate sector has been biased against wages and salaries in favor of corporate profits.

The phase of the business cycle is especially relevant when making comparisons between growth rates of profits and wages. It is incorrect to base conjectures about "bias" either in favor of profits or wages on their relative movements during only one phase of an economic expansion. Corporate after-tax profits, as shown in Chart I, have exhibited large cyclical varia tion, falling shaply during economic contractions and rising rapidly during recoveries. Wages and salaries. on the other hand, have declined relatively little dur" ing econonic contractions in the past 20 years and have risen steadily, but more slowly than profits, in the recovery period.

The ratio of componate after-tax profits to compensation of employees in the nonfinancial comporate sector

\footnotetext{
${ }^{1}$ Council of Economic Advisers, The Economy at Mid-1972 (August 1972), p. 46 .
}

is esed to compare the relative movements of profits and wages in the present recovery with past cyclical movements. An increase in this ratio indicates that the profits share of corporate income is rising relative to the wages share.

As shown in Chart II, the ratio of profits to wages has exhibited large cyclical variation. In general, the ratio has risen steadily following a trough in economic activity, has peaked about midway through the expansion and then has begun to decline. This decline has continued in the peak-to-trough period of the business cycle and then has reversed in the following recovery period. Over the early stage of a business cycle expansion the share of corporate income going to profits has risen, but during the later phase of an economic expansion the wages share has risen relative to the profits share.

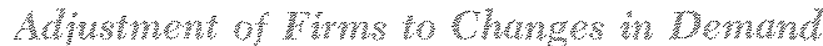

The goal of a business firm is to maximize the wealth of owners." Therefore, the firm must consider not only current profits, but also expected future profits. Actions taken by the firm in the current period to alter its level of employment and size of capital stock can be expected to affect its operations in future periods. The cyclical movement of the ratio of profits to wages reflects the process by which firms adjust to changes in product demand.

At any point in time, business firms have a stock of capital that is the result of past investment decisions, This inherited capital stock can be considered a fixed factor when analyzing the short-run response of business firms to deviations in demand from expected levels. ${ }^{3}$ Although the stock of capital is fixed in the

2 For an additional discussion of points raised in this section, see Armen A. Alchian and William $\mathrm{R}$, Allen, University Eeonomics, 3rd ed. (Belmont, California: Wadsworth Publishing Co., 1972), especially Chapters $15,16,17$ and 18 .

The degree of variability associated with a factor is most usefully considered in terms of the costs involved in altering the inputs of that factor. "When a proprietor says that he can quickly buy more steel sheet, but requires 7 months to obtain 


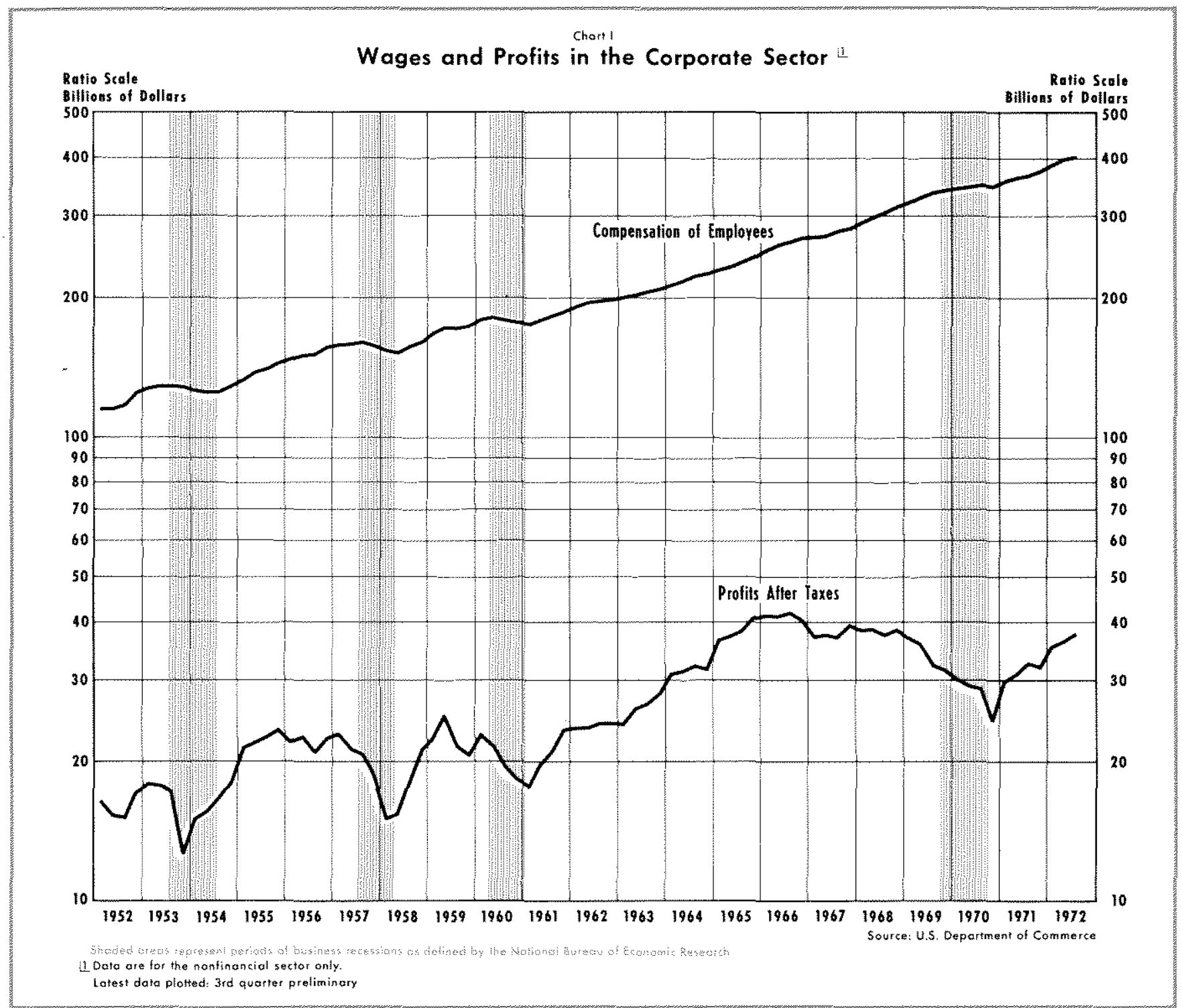

short run, within limits, firms can vary the utilization rate of the inherited capital stock.

Firms base their capital expansion plans on expectations of future demand for output, inflation, and future labor costs relative to capital costs. Given these expectations, as well as other factors, firms attempt to

a new stamping machine, he 1 s not being precise. At a suf ficiertly high price, one can buy a stamping machine from another company and have it installed in 24 hours; at a very high cost one can have a new machine built in a month by working around the clock. When we say that in the short run some inputs are freely variable, we mean that their quantity can be varied without affecting their price (for given quality). When we say that other imputs are not freely variable we mean that their quantities can be vatied within the given cime unit - be it a week, a month, or a year - only at a considerable change in their price: if we try to sell the specialized machine, it has little vaue in other uses; af we try to buy more, price rises sharply for early delivery." See George I. Stigler, The Theory of Price, 3rd ed. (New York: MacMillan Co., 1966), pp. 134-135. adjust their capital stock to produce an expected level of output at minimum cost. If output demand deviates from what firms had expected, firms will find the scale of plant they have constructed is larger or smaller than what they would have built had they accurately forecast output demand.

For example, consider the case of a fall in demand for goods and services. Suppose firms had built up a capital stock during the previous expansion based on expectations of continued increases in demand. The scale of plant firms have constructed will be larger than what they would have built if they had correctly anticipated the slowing in output demand. Consequently, per unit costs of producing the actual output rate will be greater than if firms' expectations had been realized. 


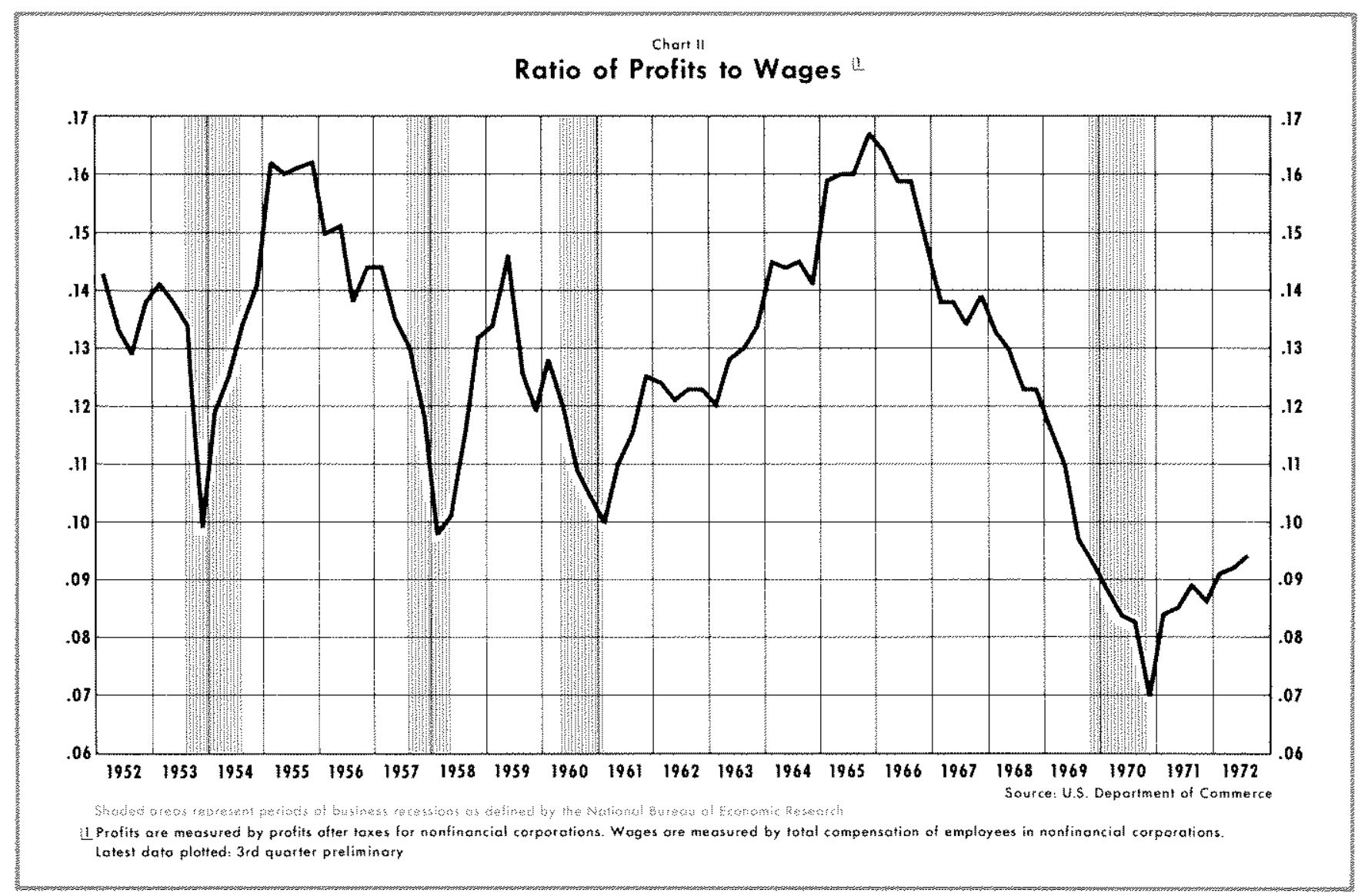

In the early stages of an economic recovery, the per unit cost of output falls as demand increases such that firms operate their inherited capital stock at lowest minimum average cost. If, as the expansion proceeds, demand expands more rapidly than firms can economically expand their capital stock, then per unit costs begin to rise.

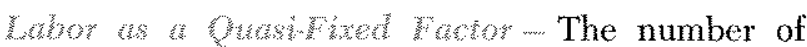
workers employed by a firm is usually considered to be more variable in the short run than the stock of capital. However, a strong case has been made that, in the short run, a firm's labor force should not be considered a completely variable factor, but as a quasifixed factor. A quasi-fixed factor has been defined as one where total employment cost is partially variable and partially fixed.

From a firm's viewpoint labor is surely a quasifixed factor. The largest part of total labor costs is the variable-wages bill representing payments for a flow of productive services. In addition the firm or dinarily incurs certain fixed employment costs in hiring a specific stock of workers. These fixed employment costs constitute an investment by the firm in its labor force. As such, they introduce an element of capital in the use of labor. Decisions regurding the labor input can no longer be based solely on the current relation between wages and marginal value products but must also take cognizance of the future course of these quantities. ${ }^{*}$

Treating labor as a quasi-fixed factor has very important implications for the short-run response of firms to unexpected changes in demand for output. The greater the costs of hiring and training workers, the less variable the resource becomes. Therefore, firms react to changes in output demand by varying the rate of utilization of labor as well as changing the level of employment.

Faced with a deviation of output demand from expected levels, firms do not know whether the change is only a very short-run phenomenon, or a permanent change in demand. Suppose that firms did react to every short-run increase or decrease in product demand by changing the level of employment. If the change in product demand turned out to be only a temporary phenomenon, then firms would again have to alter their employment as product demand returned to its previous level. The period of

4Walter Y. Oi, "Labor as a Quasi-Fixed Factor" Journal of Political Economy (Chicago: University of Chicago Press, 1962), p. 539 . 


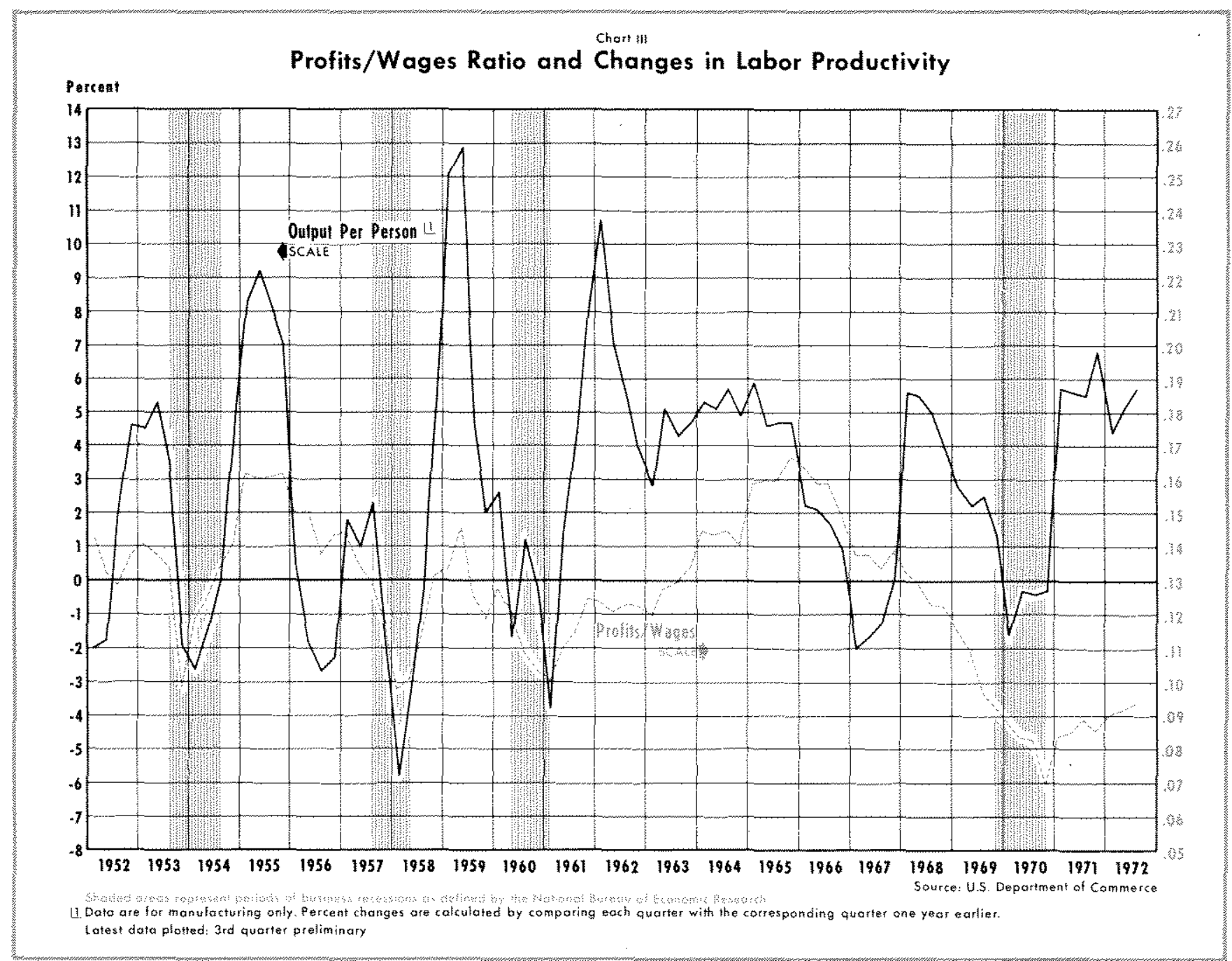

employment would be shortened, and hence the period over which fixed employment costs could be amortized would be shortened. ${ }^{5}$

Therefore, firms tend to hoard workers in the initial phases of a downturn in demand, making most of the adjustment to labor inputs in the form of a decreased utilization rate of their labor force. As the decrease in demand is maintained, firms eventually find it less costly to alter the size of their labor force, and employment begins to fall more rapidly. During upswings in demand, firms find it less costly to increase the utilization rate of their existing labor force, rather than incur large fixed costs involved in hiring and training new workers. When the added costs of increased utilization of labor exceed the costs associated

5:the periodic rent, representing the amortization of these fixed employment costs, drives a wedge between the marginal value product and the wage rate" See Oi, "Labor as a Quasi-Fixed Factor," p. 542 . with altering labor inputs by adding more workers, employment begins to rise. ${ }^{6}$

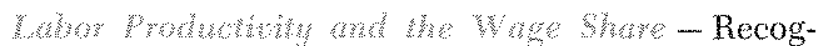
nizing that in the short run firms may vary the utilization rate of capital and that the number of workers employed by a firm is a quasi-fixed factor, rather than a completely variable factor, one can construct an explanation for the observed inverse relationship between measures of labor productivity and the wages share of corporate income over the business cycle. As shown in Chart III, an acceleration in output per person is associated with a decrease in the labor share relative to the profits share (a rise in the profits/wages

64 Less costly" refers to the present value of costs, not necessarily to current costs. The discounted cost of hiring an additional worker is the sum of the present value of expected wage payments and hiring-training costs. Profit maximization resulss when the discomted costs of a worker just equal the discounted revenue generated by the worker. 
ratio). A deceleration in output per person is associated with a rise in the labor share.

When output demand deviates from what firms had expected, firms adjust their inputs of capital and labor. Adjustments are based on the relative costs of available alternatives. In the short run, the costs to firms of adjusting their stock of capital is very large, hence firms adjust the utilization rate of the existing capital stock. ${ }^{\top}$ Because of the quasi-fixed nature of the firm's labor force, most of the adjustment in labor inputs initially occurs in the utilization rate of the labor force rather than the level of employment.

When the demand for output falls short of what firms expected, the number of workers is reduced less than proportionately to the decrease in output. The interrelated effects of a reduction in capital utilization and labor force utilization result in a sharp drop in output per person. When demand for output exceeds expected levels, firms increase the utilization rate of capital. Because of the costs of hiring and training new workers, firms tend to increase the utilization rate of their existing labor force. Consequently, output per person rises rapidly.

As the economic expansion continues, firms increase their level of employment. In many cases, the added workers will make less of a contribution to output than members of the firm's existing labor force. New workers must be trained to perform the tasks specific to the firm. During the initial traixing period, the new workers' marginal product is very low as trained work ers must devote part of their time to instructing the new workers. Consequently, the growth in output per person slows markedly.

These cyclical fuctuations in output per person do not imply that workers suddenly become much less "productive" in cyclical downturns or much more "productive" in uptums. The cyclical pattern of output per person is endogenously determined in the process by which firms adjust to deviations in output demand from expected levels.

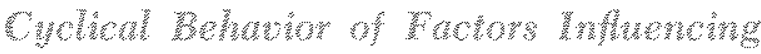

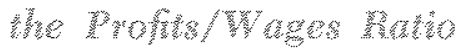

The movements of factors influencing the cyclical behavior of the profits/wages ratio since the third quarter of 1953 are presented in Table I. There are two major sets of factors in these tables. The first set represents cost factors such as wage rates (compensation per manhour), unit labor costs, output per person,

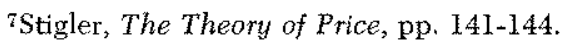

and costs of material inputs (wholesale prices of industrial commodities). The second set of factors represents adjustment factors by firms. These include employment, manhours (employment times average weekly hours), capacity utilization, prices of output of finished goods in manufacturing, and output.

The top tier of Table I illustrates the movements of these factors in the initial stages of an expansion in aggregate demand, covering the period from trough to four quarters later. The middle tier divides the trough-to-peak period of each cycle in half in order to show the differences in the movements of these factors after an economic expansion has become fully developed. The bottom tier illustrates the movement of these factors from the peak in economic activity to the trough. This comparison shows adjustments of these factors to a marked slowdown in demand from its previous expansion path. These tables are intended to illustrate the general relative movements of these factors, not to represent precise numerical relationships between the factors.

A rising profit share does not correspond to a more rapid increase of output prices relative to wage rates. Periods when the profit share rises rapidly are periods of very moderate increases in output prices in the manufacturing sector. As output prices accelerate, the profits share actually begins to fall. Movements in the profits/wages ratio appear to be most closely related to changes in output per person, which reflect the adjustment of firms to cyclical variations in output demand.

As shown in Table $I$, in the initial stages of an expansion in demand in the manufacturing sector, prices of manufactured goods increase moderately. However, capacity utilization rises rapidly and, although employment also rises, manhours rise more rapidly representing increased utilization of the employed labor force. Consequently, output per person rises very rapidly and unit labor costs decline. Profits expand sharply while compensation of employees rises moderately.

As shown in the second tier of Table I, after the expansion has fully developed, output prices rise more rapidly, but so do wage rates. The rapid increase in capacity utlization halts, and the expansion in labor inputs now appears mostly as increased employment. The growth of output per person slows markedly to about a 1.5 percent rate, and unit labor costs rise. The growth of profits halts while wages continue to expand.

When demand falls, as shown in the third tier of Table I, firms decrease output by adjusting downward 
FACTORS INFLUENCING PROFITS/WAGES RATIO

(Annual Rates of Change)

Trough to Four Quarters Later

\begin{tabular}{|c|c|c|c|c|c|c|c|c|c|c|c|}
\hline Period & $\begin{array}{l}\text { Woge } \\
\text { Ratel }\end{array}$ & $\begin{array}{c}\text { Unit } \\
\text { Labor } \\
\text { Cost2 } \\
\end{array}$ & $\begin{array}{c}\text { Oufput } \\
\text { Per } \\
\text { Persan:3 } \\
\end{array}$ & $\begin{array}{c}\text { Wholesale } \\
\text { Prices of } \\
\text { Industriol } \\
\text { Commodities } \\
\end{array}$ & Employment & Manhours 4 & $\begin{array}{c}\text { Capacity } \\
\text { Utilization }\end{array}$ & $\begin{array}{l}\text { Output } \\
\text { Prices } \\
\end{array}$ & Output & Profits ${ }^{2}$ & $\begin{array}{c}\text { Campensotion } \\
\text { of } \\
\text { Employees }\end{array}$ \\
\hline $111 / 54-111 / 55$ & $4.2 \%$ & $-1.6 \%$ & $8.0 \%$ & $6.7 \%$ & $5.6 \%$ & $7.7 \%$ & $8.9 \%$ & $-0.8 \%$ & $14.1 \%$ & $35.3 \%$ & $12.0 \%$ \\
\hline $11 / 58-11 / 59$ & 4.9 & -4.1 & 12.9 & 2.3 & 6.9 & 10.4 & 16.4 & 1.3 & 20.8 & 63.0 & 13.2 \\
\hline $1 / 61-1 / 62$ & 4.4 & -4.1 & 10.7 & -0.3 & 3.8 & 5.5 & 9.6 & 0.9 & 14.9 & 33.3 & 8.2 \\
\hline$N / 70+1 V / 71$ & 5.4 & -0.2 & 6.8 & 3.3 & -0.6 & 0.7 & 0.5 & 2.6 & 6.3 & 30.6 & 7.4 \\
\hline
\end{tabular}

\section{Trough to Mid-Point of Expansion and Mid-Point of Expansion to Peak}

\begin{tabular}{|c|c|c|c|c|c|c|c|c|c|c|c|}
\hline Period & $\begin{array}{l}\text { Wage } \\
\text { Ratel }\end{array}$ & $\begin{array}{l}\text { Unit } \\
\text { Labor } \\
\text { Cost } \\
\end{array}$ & $\begin{array}{c}\text { Output } \\
\text { Per } \\
\text { Person } 3 \\
\end{array}$ & $\begin{array}{l}\text { Wholesale } \\
\text { Prices of } \\
\text { Industrial } \\
\text { Commodities } \\
\end{array}$ & Employment & Manhours: & $\begin{array}{c}\text { Capacity } \\
\text { Utilization } \\
\end{array}$ & $\begin{array}{l}\text { Oulput } \\
\text { Prices }\end{array}$ & Output & Profits 7 & $\begin{array}{c}\text { Compensation } \\
\text { of } \\
\text { Employes }\end{array}$ \\
\hline $\begin{array}{l}111 / 54+1 / 56 \\
(6 \text { quarters) }\end{array}$ & $4.6 \%$ & $2.3 \%$ & $3.5 \%$ & $3.5 \%$ & $4.9 \%$ & $6.2 \%$ & $5,6 \%$ & $-0.2 \%$ & $8.7 \%$ & $21.6 \%$ & $11.9 \%$ \\
\hline $\begin{array}{l}1 / 56-111 / 57 \\
\text { (6 quarters) }\end{array}$ & 6.8 & 4.1 & 1.4 & 3.1 & -0.5 & -1.5 & -4.0 & 2.8 & 0.9 & -4.2 & 5.7 \\
\hline $\begin{array}{l}11 / 58-11 / 59 \\
\text { (4 quarters) }\end{array}$ & 4.9 & -4.1 & 12.9 & 2.3 & 6.9 & 10.4 & 16.4 & 1.3 & 20.8 & 63.0 & 13.2 \\
\hline $\begin{array}{l}11 / 59-11 / 60 \\
\{4 \text { quarters })\end{array}$ & 4.5 & 4.7 & -1.7 & 0 & 0.9 & -0.6 & -3.8 & 0.6 & -0.9 & -13.9 & 4.9 \\
\hline $\begin{array}{l}1 / 61-11 / 65 \\
(18 \text { quaters }\end{array}$ & 3.9 & -1.4 & 6.5 & 0.4 & 2.8 & 3.5 & 4.5 & 0.7 & 10.1 & 25.6 & 7.8 \\
\hline $\begin{array}{l}111 / 65-1 V / 69 \\
\text { (17 quarters) }\end{array}$ & 6.5 & 4.2 & 1.6 & 2.7 & 2.4 & 2.2 & -1.3 & 3.3 & 4.2 & -4.0 & 10.2 \\
\hline
\end{tabular}

\begin{tabular}{|c|c|c|c|c|c|c|c|c|c|c|c|}
\hline \multicolumn{12}{|c|}{ Peak to Trough } \\
\hline Period & $\begin{array}{l}\text { Wage } \\
\text { Ratel }\end{array}$ & $\begin{array}{l}\text { Unit } \\
\text { Labor } \\
\text { Cost }\end{array}$ & $\begin{array}{c}\text { Outpuł } \\
\text { Per } \\
\text { Person } 3\end{array}$ & $\begin{array}{l}\text { Wholesale } \\
\text { Prices of } \\
\text { Industrial } \\
\text { Commodities }\end{array}$ & Employment & Monhours4 & $\begin{array}{c}\text { Capacity } \\
\text { Utilization }\end{array}$ & $\begin{array}{l}\text { Qutput } \\
\text { Prices }{ }^{6}\end{array}$ & Output & Profits ${ }^{7}$ & $\begin{array}{c}\text { Compensation } \\
\text { of } \\
\text { Employees } \\
\end{array}$ \\
\hline $111 / 53-111 / 54$ & $4.1 \%$ & $2.7 \%$ & $0 \%$ & $-0.5 \%$ & $-9.0 \%$ & $-10.2 \%$ & $-13.7 \%$ & $-1.4 \%$ & $-9.0 \%$ & $-3.5 \%$ & $-3.4 \%$ \\
\hline $111 / 57-11 / 58$ & 3.6 & 7.7 & -6.0 & -0.5 & -11.2 & -13.3 & -19.1 & 1.0 & -16.8 & -34.1 & -6.5 \\
\hline $1 / / 60.1 / 61$ & 1.9 & 3.1 & -2.7 & -0.5 & -6.5 & -8.0 & -11.5 & -0.3 & -9.0 & -24.1 & -3.1 \\
\hline $1 \mathrm{~V} / 69 \cdot \mathrm{lV} / 70$ & 7.7 & 5.8 & -0.3 & 3.7 & -7.3 & -9.2 & -12.0 & 4.5 & -7.6 & 22.5 & 2.0 \\
\hline
\end{tabular}

1Employee compensation divided by manhours.

"Employee compensation diviced

Compensation diviced by output

. Ontput divided by employment.

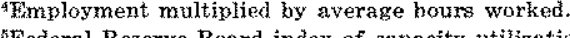

${ }^{5}$ Federal Reserve Board index of capacity utilization.
oConsumes price index of commodities less fors.

BConsumer price index of commudities less forl.

s Compensation of employees int nonfinaneial corporations.

\% NOTE; Profits and compensation of employees data pertain to nonfinancial corporations, All other data pertain to total manufaeturing. 


\section{An Alternative Measure of the Profits Share of Corporate Income}

The introduction of tax laws permitting more liberal asset depreciation in recent years has led some observers to question the comparability of profits in previous periods with profits in more tecent pertods. The basis for suel a view is that, of frms are depred ating caplal at a faster rate than in previous business: cyeles, then the fall $\mathrm{n}$ the profits/ wages natio would be somewhat greater and the rise somewhat less than previously One way to set an upper bound on the possible bias introduced into recent novenents of the profts / wages ratio by accelerated depreciation is to use the casl flow/wages ratio /n this ratio, depredation, estimated by reported capital consumption al lowances, $\mathrm{s}$ added to aftertax profts,

The cash flow/wages ratio is presented in Chart IV along with the proflts/ wages ratio for comparison pur poses. Relative to previous peak to trough periods, the most recent decine in the cash flow/wages ratio ts less pronounced than the dedine in the plofits/ wages ratio, The general pattem of movement of the two ratios is essentially the same, The cffect of adding an estimate of depreciation nto the ratio is to redice the magnitude of the cyclical variations of the ratio.

Companing the expansion peak in the eash flow/wages ratio and the expansion peak of the profits / wages tatto to their business cyde trough values gives the following annual rates of change

\begin{tabular}{|c|c|c|}
\hline & Profits/Wages & Cash Flow/Wages: \\
\hline $\mathrm{II} / \mathrm{s}$ & $-151 \%$ & $-6.4 \%$ \\
\hline $\mathrm{I} / 6 \mathrm{~T}$ & -18.0 & -7.8 \\
\hline $1 \mathrm{~V} / 65 \sim \mathrm{IV} / 70$ & -11.6 & $-5,7$ \\
\hline
\end{tabular}

their rate of capital and labor utilization. Consequently, output per person falls, and since wage rates continue to rise, unit labor costs rise. Otutput prices decrease or rise less rapidly than wage rates. Profits fall dramatically while total wages decrease only slightly,

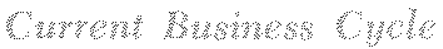

As shown in Chart II, the behavior of the profits/ wages ratio in the prolonged economic expansion that began in early 1961 and peaked in the fourth quarter of 1969 was very similar to previous periods of expanding economic activity. About midway through the expansion the ratio peaked and the wages share began rising relative to the profits share. By the end of 1969 , the profits/wages ratio had fallen to about the same level as at the start of the recovery in early 1961. From trough to peak, the ratio averaged 0.133. This compares with previous trough-to-peak averages
Variations in after tax profits are much greater that variations in depreciation over the cycle. For example, from the midpoint in an expansion to the trough of the business cycle, after-tax profits fall while reported depreciation continues to rise. In the two previous comparable business cycle periods, the rate of decline of the profits/wages ratio was approximately twice as great as the cash flow/wages ratio, and this relationship has continued in the most recent period.

On balance, use of the after-tax profits/wages ratio does not appear to bias significantly the analysis of relative movements of profits and wages. In the last few years, any downward bias introduced into reported after-tax profits by accelerated depreciation has been largely, if not completely, offset by the effect of inftation on the replacement cost of capital, technological obsolescence, and obsolescence due to nore restrictive laws such as pollution control and safety. Tax laws require that reported depreciation be based on original cost In a period of accelerating inflation replacement costs exceed original cost. For some capital goods, such as computers, rapid technological change has made capital purchased by firms economically inefficient before it has been fully depreciated. 2 In other industries, subject to more restrictive laws on pollution and safety, technically efficient means of production have been rendered economically ineffcient die to the large added costs of modifying existing equipment to meet pollution or safety standards.

2For a discussion of economic effictency and teehnical ef ficlency see Armen $\mathrm{A}$. Alchan and Willan $\mathrm{N}$. Allen, University Economics, 3rd ed (Belmont, Califonnas Wads woth Publishing $\mathrm{Co}_{3}, 1972$ ), especially Chapter 20

of 0.125 in the period II/ 1958 -II/ 1960 and 0.147 in the period III/1954-III/ 1957.

From the fourth quarter of 1969 to the business cycle trough in the fourth quarter of 1970 , this ratio fell to its lowest level in the preceding 20-year span. The profits share of corporate income fell markedly relative to the wages share as the ratio reached 0.070 , compared to previous lows of about 0.100 , a level reached generally close to the troughs of earlier downturns.

In the first two quarters of 1971 , the profits/wages ratio rose from its historically low level at the end of 1970. However, the rise was quite small compared to previous recovery periods. The ratio remained at about the same level in the first two quarters of 1971 as in the second and third quarters of 1970 , noticeably below any level experienced in the previous 20 years.

In August 1971 wage and price controls were instituted. In commenting on the "faimess of controls," 


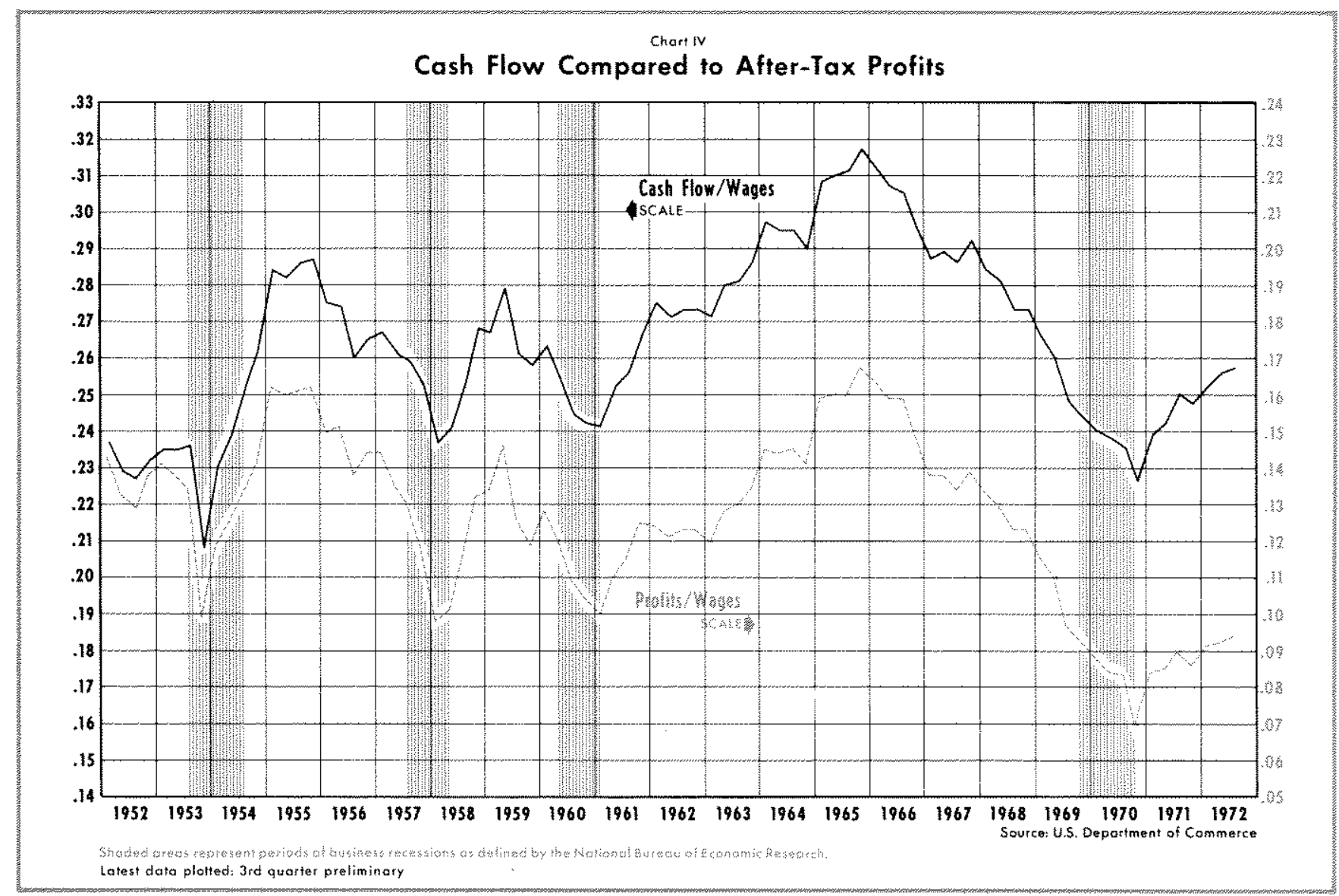

the Council of Economic Advisers (CEA) in August 1972 stated:

If these standards were precisely and universally followed, the outcome would be somewhere between preservation of the relative shares of wages and profits as they existed at the beginning of the program and a moderate increase in the profits share such as ordinarily occurs in a business recovery although possibly of smaller size, ${ }^{\mathrm{s}}$

The profits/wages ratio rose from an average of 0.085 in the two quarters before the freeze to 0.094 in the third quarter of 1972 , a 10.6 percent rise over a period of five quarters. Therefore, one of the goals of controls, as stated by the CEA, seems to have been realized. The profits/wages ratio rose moderately after the imposition of controls and the percentage rise seems to be in line with previous recoveries. For example, the ratio rose 8.8 percent from the average of the two quarters after the trough in early 1961 to the fourth quarter of 1962 , also a period of five quarters.

However, in the same section on "faimess of controls" the CEA stated:

8 Economy at Mid-1972, pp. 46-47.
A basic principle of the system of controls is that it should try to avoid changing the distribution of income that would occur in the course of a strong noninflationary expansion....

When comparing the recent rise in the profits/wages ratio with earlier economic recoveries it appears that the distribution of corporate income is still heavily weighted in favor of wages. The profits/wages ratio was at an historically low level in the two quarters prior to controls, and even with its recent rise it has remained below any previous level in the entire period from 1952 to the present. Furthermore, it has remained below the previous trough low points of about 0.100 since the second quarter of 1969 , a period of 13 quarters. Therefore, the profits share relative to the wages share remains far below what it has been in previous expansions.

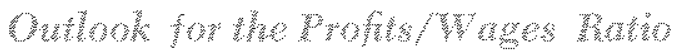

The historically low profits/wages ratio prevailing now is related to the length of the previous expansion. Given the prolonged expansion, the inherited capital stock in late 1969 was much larger than in previous expansions. As the 1961-69 expansion continued, the 
experience of significant slowdowns in demand faded into the background, while total spending and inflation accelerated giving firms an incentive to expand their capital stock. As the expansion progressed, wage demands rose rapidly inducing firms to change the factor mix of output toward more capital and less labor. Also, liberalized asset depreciation rules and changes in tax laws conceming investment tax credits during this period added an incentive for capital expansion. The 1969 downturn in economic activity left firms with a large inherited capital stock relative to the lower than expected demand for output. The result was a much sharper fall in the profits/wages ratio than in previous periods.

Given these characteristics of the current business cycle, one would expect that the current rise in the profits/wages ratio would be somewhat slower than in previous recovery periods. Output would have to expand by a greater amount to result in lowest minimum average cost given the inherited capital stock. From the third quarter of 1970 to the third quarter of 1972 , output in the manufacturing sector rose at only a 4.8 percent annual rate. ${ }^{9}$ There was almost no increase in the reported capacity utilization rate over this period. There was no increase in employment in the manufacturing sector. Average weekly

9The third quarter of 1970 is used as the comparison period instead of the fourth quarter of 1970 , the trough quarter, because of the large effect on output of the labor strike in the automobile industry in the fourth quarter of 1970 . hours rose somewhat indicating an increase in the utilization rate of existing labor force. Output prices rose at about a 3 percent rate, considerably faster than in previous expansions. Wage rates, however, also rose very rapidly compared to previous recoveries, increasing at about a 6 percent rate. As output continues to expand, firms should experience a continued rise in output per person and an improvement in profits. This would be the expected consequence of moving down along the average cost curve associated with their scale of plant.

In the absence of controls, the profits/wages ratio would be expected to continue to rise as the recovery progresses. Increases in wage rates depend upon the growth of output, but also appear to be largely determined by previous rates of price increases. If the rate of inflation continues to decelerate, then, given the way the market has operated in the past to distribute corporate income between profits and wages, a rise in the profits/wages ratio well above 0.133 , its average during the previous expansion, should seem to be indicated given the extremely low level of the ratio in the first phase of the current recovery. Any attempt to use economic controls to hold down the profits/wages ratio below this level would indicate a bias in favor of the wages share at the expense of the profits share. ${ }^{10}$

10This assumes that after-tax profits are not significantly biased by any of the factors discussed in the screened section of this article.

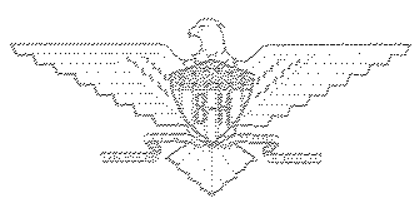

